\title{
The Research 101 Certificate Program at a \\ Community College: Giving All Students the \\ Chance to Learn Basic Information Literacy
}

\section{Skills}

Neera Mohess

Queensborough Community College, City University of New York

Abstract: Many community college students are ill prepared to do scholarly research. In order to mitigate this, librarians at our campus created the Research 101 Certificate Program in 2016. These workshops provide an access point for any student who wishes to strengthen their information literacy skill set. This essay describes the inception of the program, its pedagogical rationale, administration and participation outcomes. Suggestions for implementation at local institutions are also provided.

Keywords: community college library, community college students, pedagogy, under-prepared students, acrl framework, information literacy

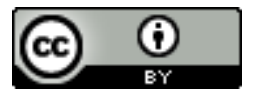

This is an Open Access article distributed under the terms of the Creative Commons Attribution 4.0 International License (http://creativecommons.org/licenses/by/4.0), which permits unrestricted use, distribution, and reproduction in any medium, provided the original work is properly cited. 
Community college students are often underprepared to do college level research. At our institution, over $70 \%$ of incoming freshmen need some form of remediation ( $Q^{\star \star}$ Factbook, 2016). A study about the information literacy (IL) skills of community college students indicates that while $60 \%$ of English 101 students have never taken a library class, $68 \%$ are required to submit a research paper assignment (Kim and Dolan, 2015). The authors conclude that "first-year college students generally lack basic information literacy skills and find it difficult to understand not only every aspect of the research process, but also the initial stage of the research process" (p.62). This lack of sufficient IL skills upon entering college and the increased complexity of college library resources, compared to high school, can be "overwhelming" (Head, 2013, p.2) to students and can generate library anxiety (Mellon 1986). As a result, these factors may negatively affect the degree to which these students locate, evaluate and incorporate credible sources into their research projects.

The one-shot library class has historically been the intervention provided to college students lacking basic IL skills. However, this method of instruction has been criticized as insufficient to become information literate. Badke (2009) states that "we need to stop believing that anyone becomes information literate (even somewhat so) in an hour" (p.49). Mery, Jewby and Peng (2012) add: "One-shot sessions cannot by their nature provide students with more than an introduction to basic library skills. Students need sustained use of library research tools to gain IL competencies" (p.368). While it is true that IL expertise is obtained through experience and practice, the basic library skills taught in one-shots serve as a foundation for underprepared students to eventually become information literate. Dreyfus (2004) describes a five stage model of the mental activities involved in skill acquisition: novice, advanced beginner, competence, proficiency and expertise. The novice can recognize the basic features of the IL landscape ( e.g. how to recognize a scholarly journal article) and is given rules for determining what action to take based on those features (e.g. how to restrict to peer-reviewed articles in a database). Many incoming students at community college are unfortunately at the prenovice stage, having never learned the basic skills required to be a novice, and perhaps without self-awareness of this 
deficiency (Mahmood, 2016). It is crucial therefore, that all college students have access to "one-shot" style classes where students can learn these basic skills. It is only when they have become an "IL novice" can they move to the more advanced stages of IL knowledge practices and dispositions, as outlined in the ACRL Framework for Information Literacy for Higher Education (2016). However, less than fifty percent of English faculty at our campus schedule a library workshop for their students and the percentage is much lower in other academic departments. And although information literacy is a learning outcome in our college's General Education requirements, we do not have a first year program or other class that requires an information literacy component. As a result of these hurdles to achieving basic IL skills, students may rely on incomplete and ad hoc techniques to locate, evaluate and make decisions about information rather than utilize the plethora of resources available to them in the library.

Ironically, many faculty members in private conversations lament about the low level of sources utilized for assignments, and the challenges in getting students to properly cite their sources. As Kim and Dolan (2015) state: "College instructors assume that incoming students would have basic writing skills when they enter college. In reality, they have little prior knowledge of the research process and soon realize that they have to do everything" (p.56). Leckie (1996) discusses the large disjuncture between "the expectations of the faculty member as the expert researcher, and the capabilities of the undergraduate" (p. 203). In the psychological literature this error in experts' predicting the performance of their inexperienced charges is called the "curse of expertise" (Hinds, 1999). It can cause difficulty both in crafting research assignments that align to the level of the underprepared researcher and also in understanding why their students perform badly in research tasks.

In an effort to study these issues, Library and English Department faculty members applied for, and received, a FIG grant in the Spring 2016 semester. FIG's (Faculty Inquiry Groups), administered through the college's Center for Excellence in Teaching and Learning, foster professional development through 
collaboration. The FIG culminated in a workshop titled "According to Google: Addressing Research-Skill Gaps What Strategies Will Help Your Students?' There were three presentations - one described how the librarian and faculty member flipped a library session, another reported on the results of an embedded librarian project, and a talk about how the Writing Center can support students who are doing research papers. During the group discussion after the presentations we brainstormed how to improve student research skills, including the possibility of how faculty might integrate IL skills into their curriculum. A Biology professor made an interesting statement. She said, "I teach content not research skills." We had not heard this before. Typically what we do hear is that faculty do not have enough time to bring their classes in for a library session. Reflecting on her comment led us to consider how the library could better support faculty in teaching basic IL skills to their students and also provide students with an independent means to acquire these skills (rather than "waiting" for their professor to schedule a library class).

In their study of the instructional preferences of students with below-proficient IL skills, Latham and Gross (2013) report that students prefer teaching that (1) combines demonstration with hands-on practice, (2) offers a high degree of interaction between teacher and students, necessitating a small class size, (3) provides supplemental materials in the form of handouts, (4) incentivizes instruction (through faculty buy-in) and (5) is sufficiently advertised to both students and faculty (pp. 445-446). The first three points concern instructional design and the remaining two deal with marketing and advertising.

\section{Instructional Design}

The first significant consideration in creating the workshops was the busy nature of the average community college student. Many work full time and have families to take care of, so we decided to create sessions that last sixty minutes. Second, from our own experience, teaching a library workshop that is not anchored to a research assignment can create "Why am I here?" motivational challenges for students (Latham and Gross, 2013, p.430). As a result, we focus on the minimum practical content a typical community college 
student would need to know when faced with a research assignment and convey that in our marketing of the program.

In order to facilitate retention of concepts and skills, we embed two pedagogical strategies in our Research 101 (R101) instruction: testing and immediate practice. Testing of concepts has been shown to be "superior to additional study" in terms of increasing overall retention (Cary, 2014, p. 101) and engages a student's mind in a more demanding way than simply receiving information lecture-style (p.97). Research has also shown that students need "time on task", sufficient practice at the right challenge level, in order to accumulate benefits (Ambrose, Lovett, Bridges, DiPietro, \& Norman, 2010, p.133).

The main components of the workshop include:

- Scholarly and Non-scholarly Sources-After establishing a baseline of students' knowledge in this area (typically low) by asking what they think comprises a scholarly source, they first watch a video on the topic, and are then directed to the Scholarly \& Non-scholarly page in the Research Process (p.3) and tested by answering a 3-item quiz in their student worksheet (Mohess 2018). When we go over the answers most students can (in contrast to the beginning of the session) distinguish between a scholarly and non-scholarly source and describe the components of a scholarly source. Often, the students who give correct answers will explain their reasoning to the class and thereby help other students who are still confused.

- Beginning the Research Process - Many community college students have difficulty in the beginning phases of a research project (Kim and Dolan, 2015, p.62). Students tend to select initial topics that are too broad (e.g. "the environment", "diabetes") which frustrates their search for information. We show students how to utilize Wikipedia as a source for initial keywords (Calhoun, 2014), and techniques to narrow and refine their topic (Mohess, 2015, pp. 8-13). As a class exercise they are asked to locate 
keywords in a topic sentence and identify sub-topics in a broad Wikipedia topic (like diabetes) from the table of contents.

- Locating Credible Information: We focus on three sources of information - the web, databases, and the OneSearch discovery tool.

- Web: Students are shown to enter keywords in Google and restrict to credible top-level domains (.edu, .gov, nytimes.com), time range, and advanced search. These simple techniques are a revelation to most underprepared students. It enables them to quickly locate authoritative sources online and prepares them for a more complex, contextual evaluation of web information at a later stage when they are ready for it.

- Databases: We use the Academic Search Complete database to show students how a database is structured. They learn about database limiters, the email and citation function and are then tasked to search for a scholarly article using keywords (from the prior keyword exercise), email the article to themselves and locate the MLA citation generated by the database. They are also pointed to the "Databases by Subject" page on the college library website so that when they have discipline-specific assignments they can locate appropriate databases to do their research.

- OneSearch: Students are asked to log into OneSearch and then are shown how to locate books and articles, save them, email them and locate the citation function. They also have to locate a book in the system, write down the call number, and physically go into the stacks and bring it back to class. It is only when they have completed this last task will they receive their certificate of completion.

- Citation: Students are shown how to copy and paste the URL for a web page into ZoteroBib to generate a citation. In Academic Search Complete and OneSearch they are asked to locate, copy, paste and 
format the MLA citation for their article and book, respectively. This gives students simple tools to begin citing their sources, and are encouraged to study the MLA booklet, available in the session, so they understand the components of various sources and can correct any errors they find in ZoteroBib and database citations.

To facilitate solo practice after attending an R101, students are given a set of handouts. The R101 student worksheet details all of the steps in locating and citing sources (Mohess, 2018). The Research Process booklet (Mohess, 2015) is used to provide information about the differences between scholarly and nonscholarly sources and also contains additional information we are not able to cover due to time constraints (how to create a thesis statement etc.). Finally, we provide citation booklets (MLA, APA, Chicago) in the session for students to use as a reference.

In order to administer the program such that librarians can fit teaching these sessions into their schedules without undue burden, we created a shared R101 binder to be passed to each subsequent librarian after a session. The binder serves two purposes: first, it reduces librarian workload by containing all the documents needed to run and administer a session and second, it fosters a shared ownership of the program. The documents contained in the binder include the R101: librarian schedule; program procedure; class outline; attendance sheet; student worksheets; extra flyers and certificates of completion (Mohess 2018). Additionally, in an effort to avoid overwhelming librarians, and to ensure we are able to provide individual support to students, the maximum number of student registrations is twenty per session.

\section{Marketing and Advertising}

At the inception of the R101 Program, we created a flyer in Microsoft Word and disseminated it to faculty via college email and to students through flyers in the library. We also placed print copies of the flyer in faculty mailboxes to share with students. 
In the Fall 2018 we outsourced the visual design of the program to our college's Marketing Department. This polished iteration of the flyer (Mohess 2018) aligns with the college's visual aesthetic and helps to validate the program even further. It is emailed to students and faculty, posted on various bulletin boards across the college, and added to campus-wide digital signage. Printed copies of the flyers are placed in faculty inboxes all departments at the start of the semester, and posted in throughout the library.

The Marketing Department creates A-Frame posters that are moved to different campus locations throughout the semester. Additionally, all of the R101 sessions are entered into the college's weekly online Events Calendar which is sent to all community college members (students, staff and faculty), with a link to register.

\section{Participation}

We piloted the R101 Certificate workshops in the Fall of 2016 with 14 sessions divided between three librarians. We partnered with the college's Honors Program to have their students complete their library research workshop requirement by attending a R101 session. Some professors made attendance a requirement or extra credit for their students. We decided to continue the program and track results.

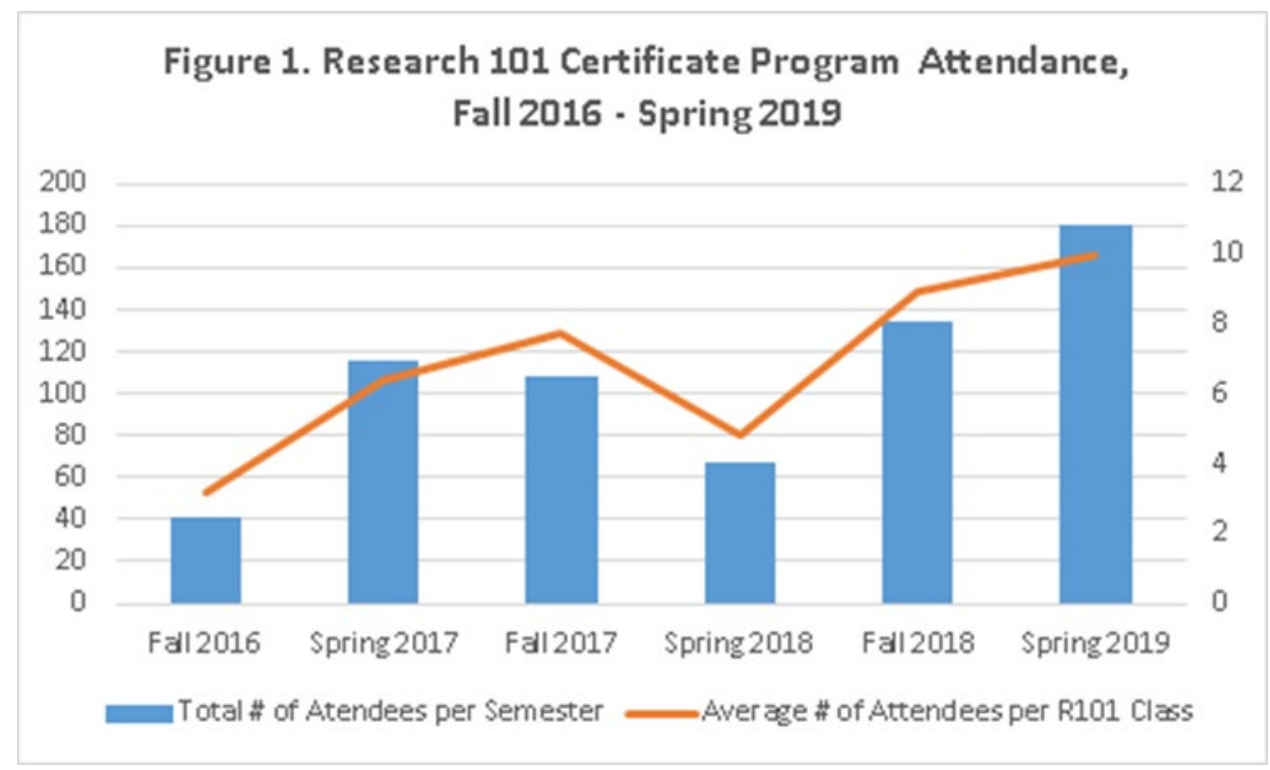

Figure 1. Research 101 Certification Program Attendance, Fall 2016-Spring 2019 
As Figure 1 indicates, the number of participants attending R101 workshops increased 339\% since its inception in the Fall 2016 from 41 in the Fall 2016 semester to 180 in the Spring 2019 semester. The average number of participants per session increased 212.5\% from 3.2 (Fall 2016) to 10 (Spring 2019).

Based on sign-in sheet data, professors in departments that have not historically sought out library classes such as Math, Biology and Physics Departments are assigning R101 sessions to their students as a class requirement or for extra credit. When we first began this program we worried it would "cannibalize" our Information Literacy program (a combination of one-shots and an embedded librarian program), since R101's do not require a professor to "take away" a class session for a library workshop. This did not happen - the number of one-shot classes has actually increased during the time frame of the R101 Program. It appears that the two distinct types of instruction classes (discipline-specific, assignment-based library workshops and "aerial view" style R101 workshops) appeal to different faculty member populations depending on their particular discipline and pedagogy needs.

While the majority of participants are students, some faculty and staff members have also attended. Faculty members say they find the session valuable as a research refresher and also as a reminder that IL skills are important for their students to learn. A professor of Criminology, after taking the workshop told us he had not realized how useful this type of instruction could be to his students and stated he would schedule a library session for his students in the Fall 2019 semester. The Writing Center covered the hourly wage for their tutors take an R101 workshop in the Spring 2019 semester since the students who seek their help writing their papers often have research questions as well.

When we began the program, our "guaranteed customers" were students from the Honors program. However, in the Fall 2018 semester that program was modified and the R101 requirement was made optional by department. We decided to expand our outreach efforts to additional community college programs and offices. We partnered with the successful ASAP Program (Accelerated Study in Associate Programs) and 
currently offer two ASAP-only Research 101 workshops every semester (ASAP students are also welcome to attend any of the 12-14 "regular" R101 workshops offered). The R101 workshops have also proven valuable to the college's freshman orientation course, ST-100 Introduction to College Life, run by the Counseling Center. ST-100 is designed to help students acclimate to college life and teach strategies for succeeding both academically and personally. While some ST-100 instructors do schedule in-class library sessions, many require their students to attend an R101 workshop. The Director of the Counseling Center praised the program at a Library Department meeting in the Spring 2019, stating that it offers a structured learning environment for students in her department.

The largest group of students over the years, based on sign-in sheet data, indicate they attend an R101 session as a class requirement or for extra credit. This implies two things: first, faculty have seen improvements in student research projects from those who attended R101's and want to give their new students the same opportunity and second, our faculty marketing has proven successful.

The second largest group of students who attend are those saw the flyer/digital signage/email and independently registered for a session. In fact, we have encountered students who have taken an R101 workshop more than once. Several students have asked that we do more to publicize the workshops since they have found them so useful in their own course work, and many others have requested that we increase the duration of the workshops to allow more time for practice. After consulting with other library faculty members we will pilot an increase in R101 length, from 60 to 80 minutes in the Fall 2019 semester, with an increased emphasis on testing and immediate practice so students better retain the information and skills in the session.

\section{Recommendations for Implementation}

There are several reasons to consider running a similar program at your institution. First, and most importantly, the Research 101 Certificate Program gives underprepared students who independently want to achieve a baseline information literacy skill set the opportunity to do so. It is a simple and effective 
workaround to not being able to offer a credit bearing IL class or a required IL component in a First Year or other program and can be scaled up or down to meet the needs of a particular student population. Second, the program provides support for faculty who want their students to know how to research but do not have the time or willingness to teach these skills themselves or schedule an information literacy session. Third, after the initial administrative and marketing set-up, the program essentially runs itself. The librarian workload averages out to about one session per semester (though some librarians volunteer to run more than one session). Based on our experiences, here are some suggestions for implementation:

- Consult with your Marketing Department. It was when our Marketing office created a college branded and visually aligned flyer in the Fall of 2018 that the program took on campus-wide import, significantly increasing student attendance. Our partnership also allows us to use marketing tools available that we had not been previously aware of: digital signage, A-Frame posters, placement in the college calendar and weekly email bulletin.

- Align the program with your institution's unique student and faculty needs. At our community college many faculty are concerned with their students' inadequate research and citing abilities. Librarians also see firsthand at the reference desk as these struggles play out with stressed students looking to complete a research project but having no idea where to even start. We aimed to create a program to mitigate these specific concerns.

- Attend college-wide workshops and meetings. As previously stated, the idea for the R101 Certificate program was borne out of a suggestion at a Faculty Inquiry Group workshop, facilitated by English and Library faculty. In the course of attending another workshop offered at CETL we met the coordinator of ASAP and in subsequent meetings with her, outlined a plan to offer ASAP-specific R101 workshops. Conversations with staff and faculty can aid in understanding their student concerns as well as spark ideas for innovative programming. 


\section{Conclusion}

It is only aftera student has learned basic IL skills (and not before) that he or she has the capacity to work towards achieving the more advanced IL dispositions outlined in the ACRL Framework for Information Literacy for Higher Education (2016). The Research 101 Certificate Program enables underprepared students to achieve these "novice" level IL skills, aligns with their teaching preferences (Latham and Gross, 2015), and embeds pedagogically sound practices into the instruction.

On a practical granular level, the Research 101 workshops help students to begin and complete a research assignment and in so doing enables them to "walk" in an information literacy sense, so that they can one day "run”.

\section{References}

Ambrose, S., Lovett, M., Bridges, M. W., DiPietro, M., \& Norman, M. K. (2010). How learning works: Seven research-based principles for smart teaching. San Francisco, CA: Jossey-Bass.

Badke, W. (2009). Infolit land-ramping up the one-shot. Online, 33(2), 47. Retrieved from https://www.researchgate.net/publication/294810003_Ramping_Up_the_One-Shot

Calhoun, C. (2014). Using Wikipedia in information literacy instruction: Tips for developing research skills. College \& Research Libraries News, 75(1), 32-33. doi:https://doi.org/10.5860/crln.75.1.9056

Carey, B. (2014). How we learn: The surprising truth about when, where, and why it happens. New York: Random House.

Dreyfus, S.E. (2004). The five-stage model of adult skill acquisition. Bulletin of Science, Technology \& Society, (24), 177-181. doi: 10.1177/0270467604264992

Framework for information literacy for higher education. (2016). Retrieved from http://www.ala.org/acrl/sites/ala.org.acrl/files/content/issues/infolit/framework1.pdf 
Head, A.J. (2013). How freshmen conduct course research once they enter college. Retrieved from https://www.projectinfolit.org/uploads/2/7/5/4/27541717/pil_2013_freshmenstudy_fullreportv2.pdf

Hinds, P. J. (1999). The curse of expertise: The effects of expertise and debiasing methods on prediction of novice performance. Journal of Experimental Psychology: Applied, 5(2), 205-221. http://dx.doi.org/10.1037/1076-898X.5.2.205

Kim, M., \& Dolan, M. (2015). “Excuse me, but what Is a research paper?”: Embedded librarian program and information literacy skills of community college students. Community \& Junior College Libraries, 21(12), 53-70. doi:10.1080/02763915.2016.1149001

Latham, D., \& Gross, M. (2013). Instructional preferences of first-year college students with below-proficient information literacy skills: A focus group study. College \& Research Libraries, 74(5), 430-449.

Leckie, G. (1996). Desperately seeking citations: Uncovering faculty assumptions about the undergraduate research process. Journal of Academic Librarianship, 22(3), 201-208.

Mahmood, K. (2016). Do people overestimate their information literacy skills? A systematic review of empirical evidence on the Dunning-Kruger effect. Communications in Information Literacy, 10(2), 199-213. doi:10.15760/comminfolit.2016.10.2.24

Mellon, C. (1986). Library anxiety: A grounded theory and its development. College and Research Libraries, 47(2), 160-165.

Mery, Y., Newby, J., \& Peng, K. (2012). Why one-shot information literacy sessions are not the future of instruction: A case for online credit courses. College \& Research Libraries, 73(4), 366-377.

Mohess, N. (2019). Research 101 certificate program materials, fall 2018. Retrieved from

\section{https://academicworks.cuny.edu/qb oers/38}

Mohess, N. (2015). The research process 2016," Retrieved from https://academicworks.cuny.edu/qb oers/14 Q** Factbook 2015-2016. (2016). URL and title redacted for double-blind peer review purposes 